\title{
CHANGE OF A HIGHWAY ROUTE CAUSED BY A ROCKSLIDE
}

\author{
Miloslav KopeckÝ ${ }^{a, *}$, Martin BrČeK ${ }^{a}$, JAnA Frankovská ${ }^{a}$, \\ Martin OndrášiK ${ }^{a}$, MAREK Fraštia ${ }^{b}$, PAVEl LiŠČÁK $^{c}$, JAN NovotnÝ ${ }^{d}$ \\ a Slovak University of Technology in Bratislava, Faculty of Civil Engineering, Department of Geotechnics, \\ Radlinského 11, 81005 Bratislava, Slovakia \\ ${ }^{b}$ Slovak University of Technology in Bratislava, Faculty of Civil Engineering, Department of Surveying, \\ Radlinského 11, 81005 Bratislava, Slovakia \\ ${ }^{c}$ State Geological Institute of Dionýz Štúr, Mlynská dolina 1, 81704 Bratislava, Slovakia \\ ${ }^{d}$ Czech geological survey, Klárov 3, 11821 Praha 1, Czech Republic \\ * corresponding author: miloslav.kopecky@stuba.sk
}

ABstract.

During the spring of 2013, a relatively large rockslide with a total area of $96,952 \mathrm{~m}^{2}$ occurred in the eastern part of the Malá Fatra mountains. The anticipated depth of the slip surfaces was from 30 to 40 metres and the volume of moving mass was estimated to be $2,000,000 \mathrm{~m}^{3}$. The maximum movement of the rockslide on the first day in March 2013 was estimated to be $43 \mathrm{~m}$. The front of the rockslide interfered with the projected D1 highway route. The paper presented here offers an analysis of the causes of the rockslide and its activity in association with the potential threat to the proposed highway.

KEYwORDS: Highway route, rockslide, slope stability.

\section{INTRODUCTION}

In March 2013, an extensive rockslide occurred in the Kralovany-Rieka quarry, also known as the quarry Sútovo. In addition to the remarkable visual and acoustic effect, the initial sudden and significant movement was also recorded on the three fixed geodetic points installed by the NDS. The dimensions of the rockslide are $580 \mathrm{~m} \mathrm{x} 280 \mathrm{~m}$. The expected depth of the sliding surfaces was estimated from 30 to $40 \mathrm{~m}$ without investigatory works and the volume of the moving masses was $2,000,000 \mathrm{~m}^{3}$ 1].

The maximum movement of the rockslide at its instigation in March 2013 was estimated to be $43 \mathrm{~m}$. The rockslide posed a significant threat not only to the rock quarry and the nearby lake used for recreational purposes, but mostly as a threat to the construction of the D1 highway, which was planned before the rockslide occurrence in the rockslide front (Fig.1 blue line). After the rock slide, one of the variants of the new route was planned on the south (Fig.1- black line - variant V-1) which was also investigated 2 and its stability assessed [3].

\section{Conditions And CAUSEs OF ROCKSLIDE DEVELOPMENT}

The geological-tectonic conditions we consider to be a decisive cause in the formation of the large-scale rockslide. There is a tectonic thrust fault in the given area, where Mesozoic sedimentary rocks of mainly dolostones and broken limestone were pushed over granites. The carbonate complex as well as the rockslide is significantly disrupted tectonically, karstificated and divided into blocks of differing extent 4 .
The thrust fault between granites and dolostones has a steep dipping toward the south to southwest and represents the main scarp area of the entire rockslide. Granites in the area of the thrust fault have the character of mylonites (clays with medium to high plasticity). The presence of the mylonites enabled the movement of dolostones along the layer with significantly low share strength. As a second cause of the rockslide we consider the more than 50 years duration of mining activities in the quarry, which has significantly weakened the heel of the slope. These facts created permissive conditions for formation of a large rockslide.

The cause of the slope movement was the extreme climatic conditions over winter and the spring of 2013. Repeated warming caused multiple melting of the snow cover and saturation of the dolomite rocks with water. The trigger of the rockslide was the melting of the thick snow cover in March and infiltration of the melted water into the open cracks in the crown of the rockslide ("Rozsadlina" cave Fig. 1).

\section{Characteristics of INDIVIDUAL PARTS OF THE ROCKSLIDE AND THEIR ACTIVITY IN THE PERIOD 2013-2014}

The rockslide is characterized on the basis of engineering geological mapping, drilling and geodetic and inclinometric monitoring performed in the time period 2013-2014.

With regard to the kinematics of the motion, the rockslide can be divided into 3 parts:

a) Western part of the rockslide 


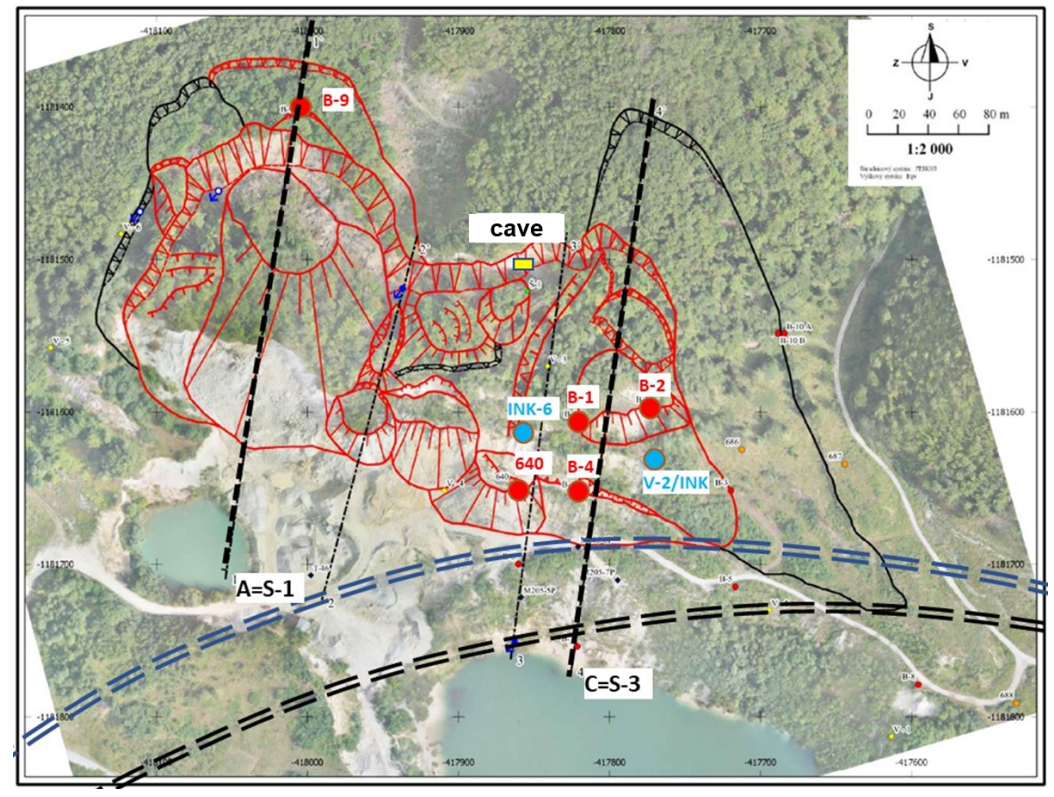

FIGURE 1. Rock and rockslide with two alternative routes of the highway, before (blue line) and after the rockslide (black line - variant V1)

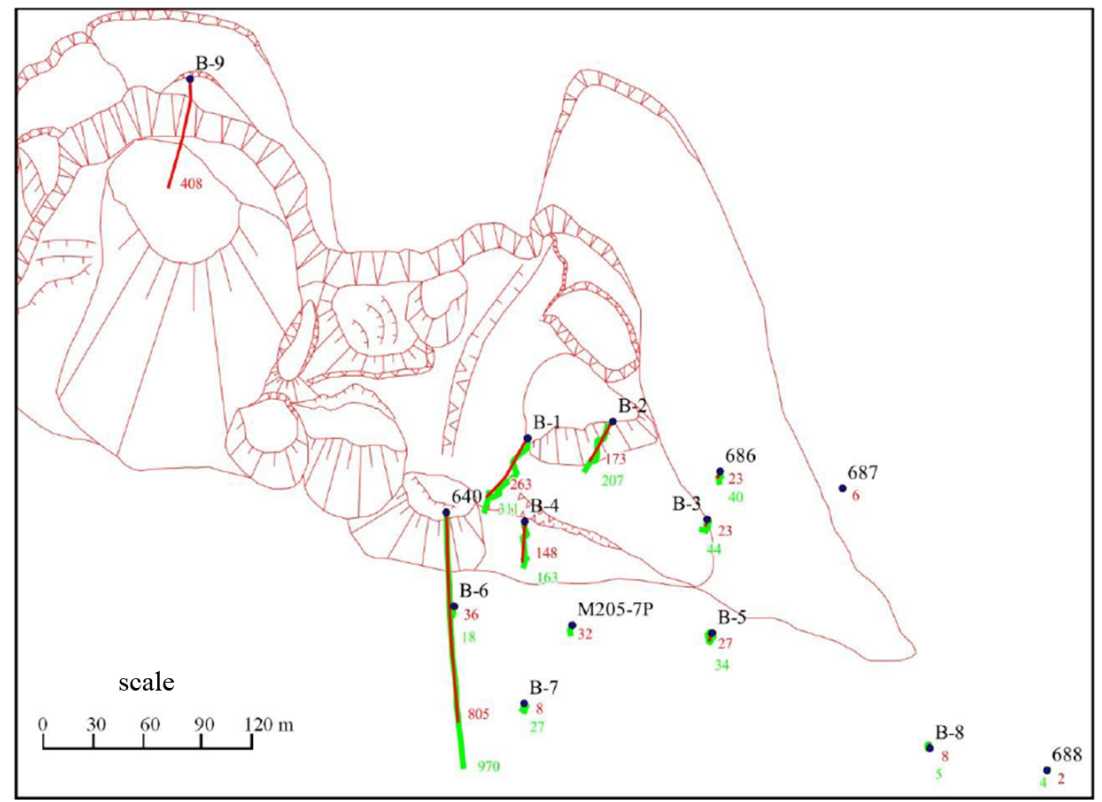

Figure 2. Vectors and absolute values of motions (in $\mathrm{mm}$ ) of geodetic points. Red color - geodetic terrestrial method (14.5. till 14.8.2013), green color GNSS measurements (14.5. till 19.9.2013)

This part of the rockslide has not been surveyed by drilling and does not touch the highway route. It consists mostly of displaced blocks of limestone with rare dolostone blocks. The relatively compact rock block is also evidenced by the quite well-preserved forest on the surface of the central part of the block, where no significant cracks were open. The depth of the planar sliding surface is assumed to be up to 35 $\mathrm{m}$ at the contact of Mesozoic rocks with Paleozoic granodiorites which, due to tectonic failure, have the character of mylonites. Above the main scarp in the rockslide crown, there is a progressive expansion of the slide, which resulted in creation of crown cracks into the granite massif. The active character of this part of the rockslide was indicated by the measurement at point B9 (Fig 2). For the period May 2013 - May 2014, the movement of the geodetic point in the direction of the slope was $1.2 \mathrm{~m}$ and its decrease was $0.76 \mathrm{~m}$. Also, at the foot of the rockslide, the pressing of the toe of the rockslide was confirmed by laser scanning (Fig. 3). A simplified mathematical model of this part of the rockslide is shown in Fig. 4

b) Central part of the rockslide

It is characterized by the most pronounced motion activity and is divided into a series of smaller 


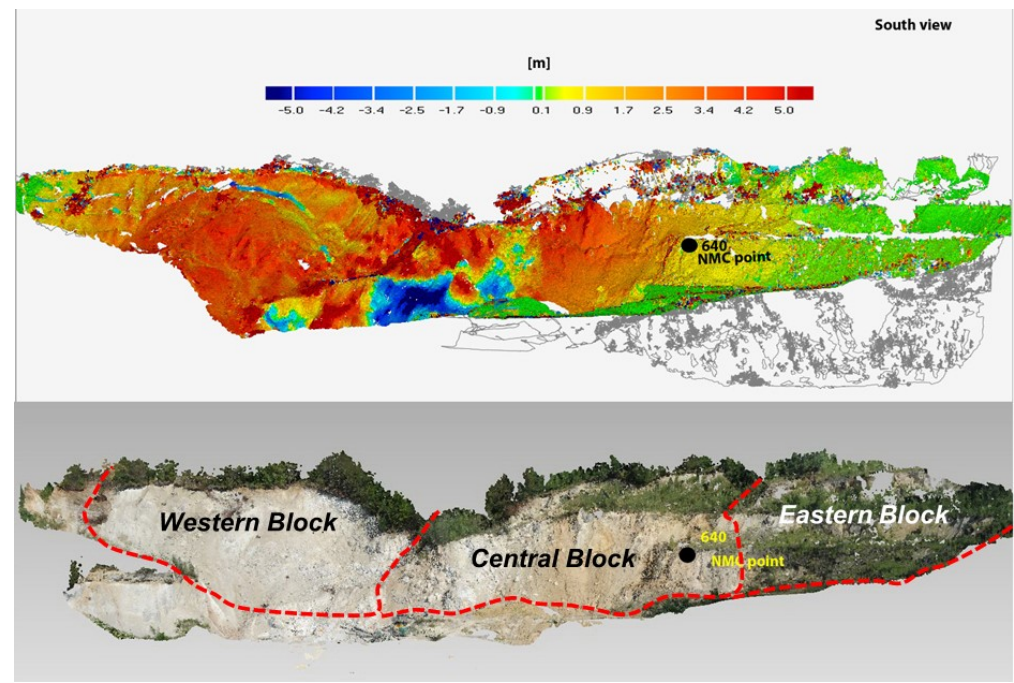

FIGURE 3. Sliding motion activity based on changes in the surface of the rockslide body detected by laser scanning (29.5. and 22.8.2013)

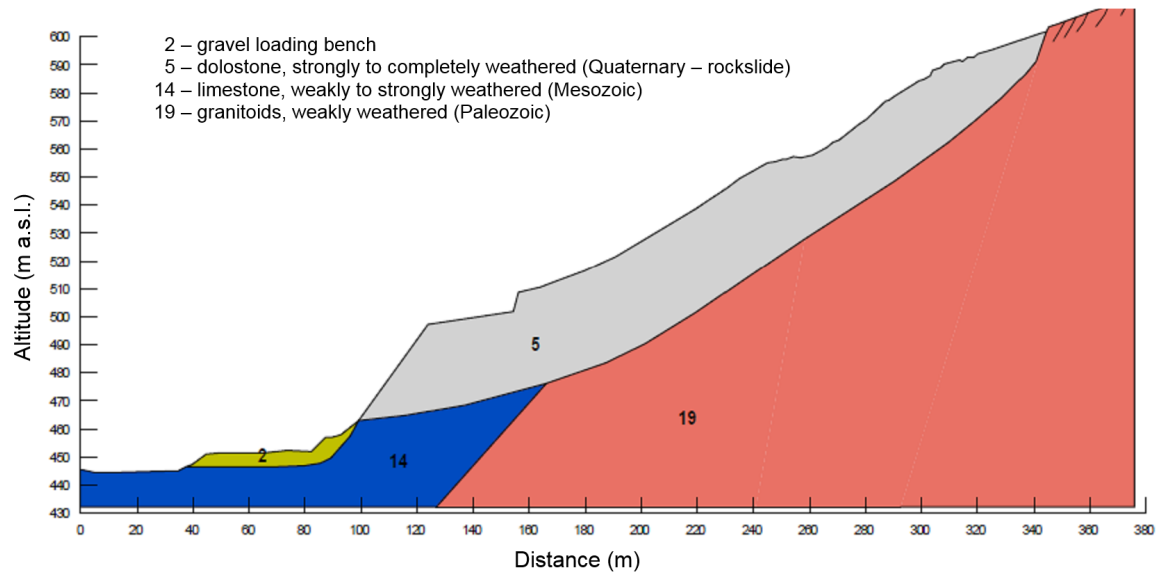

Figure 4. Computational model of the slope in profile S-1 (Fig. 1) out of contact with the highway

blocks of tectonically disturbed dolostones (Fig. 5). The blocks show, in the upper part, motion vectors towards SW and SSW and in the lower accumulation part, the direction of motion turns in a $\mathrm{N}$ - $\mathrm{S}$ direction, which is documented by the motion vector of point NDS 640 (Fig. 2). The central part of the rockslide also has a significantly developed main scarp with height about $20 \mathrm{~m}$ (Fig. 6). There is a movement of the dolostone blocks along the mylonite zone. This was verified by an inclinometric borehole INK-6 at a depth of about $25.0 \mathrm{~m}$ [5]. Rockslide activity was confirmed mainly by geodetic measurements for the period 14.5.2013 to 14.8.2013. A shift $804 \mathrm{~mm}$ was recorded at point NDS 640 (Fig. 2] 6]. The average displacement speed of the point 640 in the observed time period reached 9 $\mathrm{mm}$ per day. The activity of the front part of the rockslide was documented by laser scanning (Fig. 3). Cracks above the rockslide front were also visually well observable (Fig. 7).

\section{c) Eastern part of the rockslide}

This part of the rockslide is closest to the newly pro- posed D1 variant (variant V1 - black line in Fig. 1). Therefore, this part was examined by drilling works [2] and the slope stability calculated [3]. According to the mentioned works, it was found, as in other parts of the rockslide, that the rockslide body consisted of recrystallized tectonically disturbed dolostones. The sliding surface of the active rockslide was found at the contact of dolostones with the mylonite zone of a clay character (Fig. 8). The depth of the sliding surface is shallower than in the western and central parts of the rockslide and was determined on the basis of boreholes and geophysical measurements at a depth of 9.6 (INK-2) to $12.4 \mathrm{~m}$ below the surface. The rockslide activity in this part was confirmed by geodetic measurements (Fig. 2 - significant shifts were shown by points B-1 (263 mm), B-2 (173 mm), with a shift vector to the SW and point B-4 (148 mm) with vector shift to the south. 


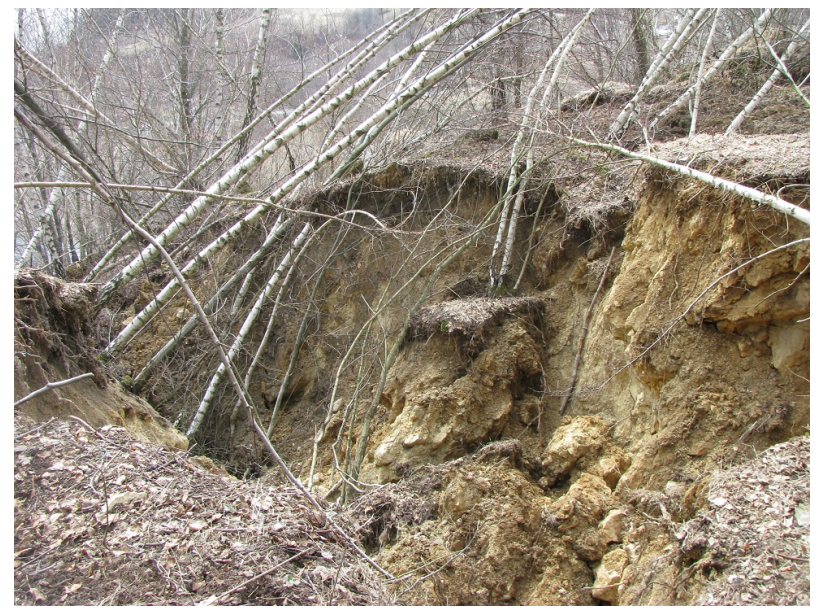

FiguRE 5. Significant radial cracks between two blocks of the central part of the rockslide

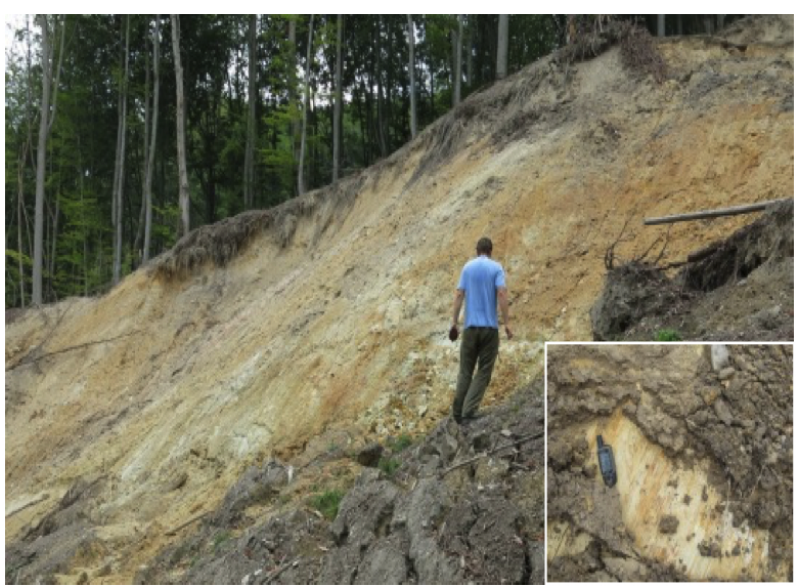

Figure 6 . Crown of the rockslide with the sliding surface in the central part of the rockslide (detail of sliding surface in mylonites)

\section{Slope stability CAlCUlations \\ AND A PROPOSAL FOR ROCKSLIDE REMEDIATION}

The highway route was designed as a viaduct near the front of the active rockslide. The conceptual design of the slope stabilization consisted of 2 basic methods [3]:

- remediation by force elements in the form of anchored reinforced concrete blocks and pile walls,

- massive loading benches in the heel of the slope, reinforced or not reinforced according to the inclination of the forehead.

Stability calculations have led to the conclusion that a solution using force remediation elements is almost impossible due to the extent of the rockslide. Therefore, this remedial action was not recommended.

On the other hand, a solution using massive loading benches seemed to be potentially a possible method of remediation. The loading benches themselves were designed from a stony material, permeable enough

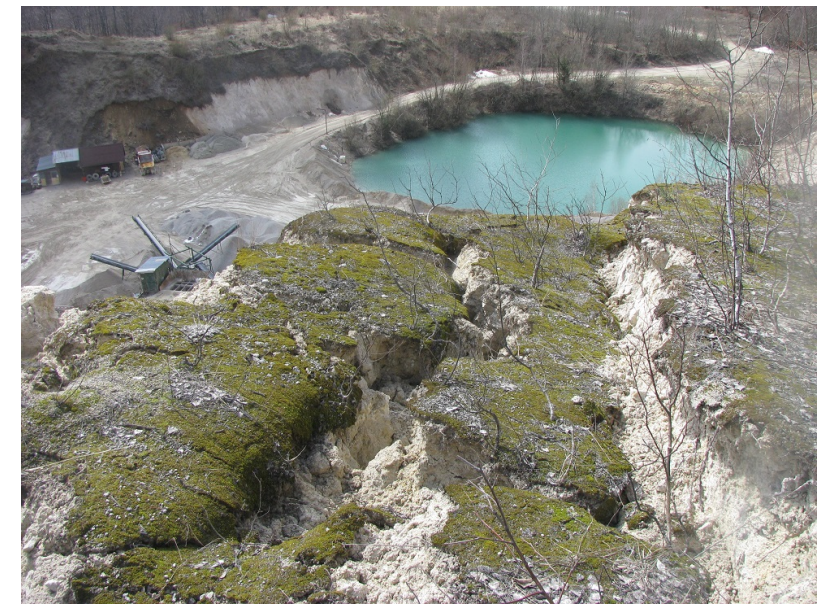

FiguRE 7. Cracks above the front of the rockslide in the central part near the point 640

even after compaction to ensure trouble-free drainage of water from the rockslide and to prevent a rise of the groundwater level at the contact between the rockslide and the loading bench. The stony material used for the construction of the load benches must meet the condition of long-term stability of the fragments. They should not soften after their incorporation into the structure, as this would cause undesired deformations of the bench and closure of macro pores, and as a result of which creep and undesired reduction of permeability could occur. The method of remediation using massive loading benches must be supplemented by remediation measures ensuring both surface and deep drainage of the rockslide.

The heel of the loading benches will extend into the current lakes. Here, it is necessary to pay attention to the unverified properties of rocks at the bottom of the lakes when setting up a high loading bench. The nature of the underlay rocks will need to be verified by investigation work.

One of the several considered alternatives of the slope stability remediation with a loading bench is shown in Fig. 9 .

\section{Conclusions}

In March 2013, an extensive rockslide occurred in the quarry Kralovany-Rieka. In addition to the quarry, the quarry workers and people using the lake for recreational purposes, the rockslide endangers the route of the projected D1 highway. Therefore, a new variant of the D1 highway route (taking it further from the rockslide front) was proposed, which was then examined and its slope stability calculated.

Monitoring observations (geodetic and inclinometric measurements) confirmed in 2013 that the rockslide is still active, e.g. the geodetic point NDS showed a movement of about $9 \mathrm{~mm}$ per day. Stability calculations have shown that stabilization of the rockslide above the highway route cannot be performed by use of force elements only, but needs more measure objects, 


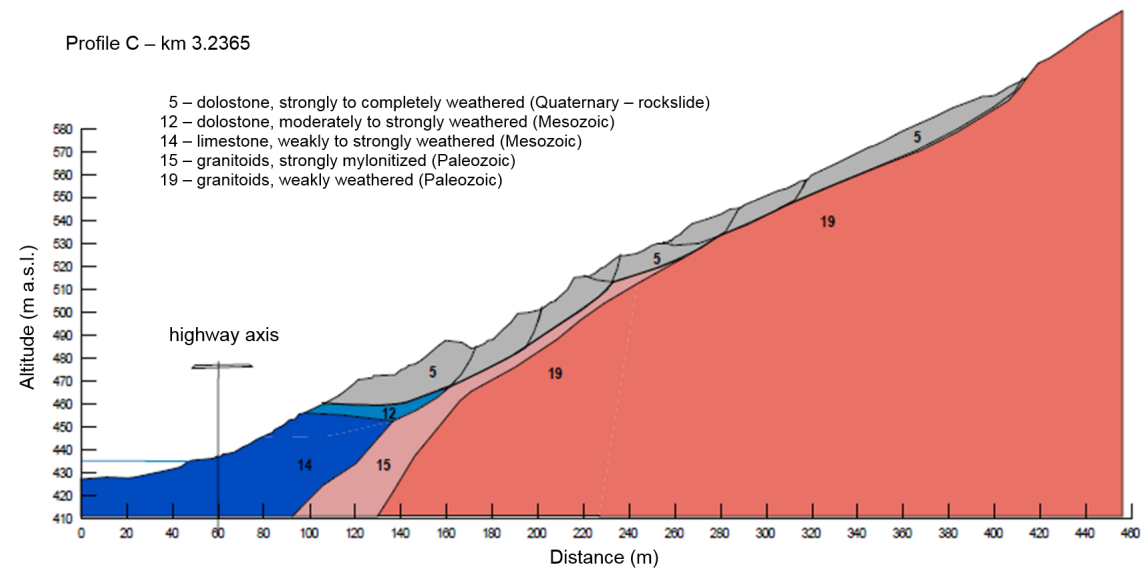

Figure 8. Computational model of the slope in the profile $\mathrm{C}=\mathrm{S}-3$ (Fig.1) in contact with the highway.

The active character of the rockslide in the vicinity of V-2 / INK is also confirmed by the results of inclinometric measurements, which for the period from 18 March 2014 to 21 May 2014 showed movement of the casing by $10 \mathrm{~mm}$

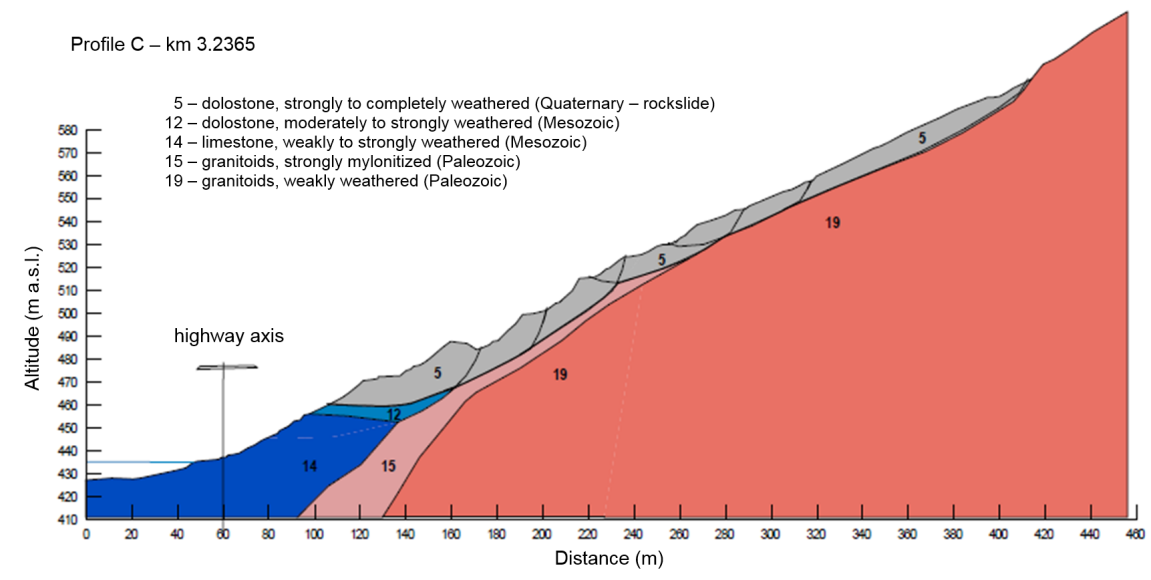

Figure 9. Computational model of the slope in the profile $\mathrm{C}=\mathrm{S}-3$ (Fig. 1) with a loading bench

such as a loading bench in front of the rockslide.

At present, however, it has already been decided that the so-called "valley variant" of the highway route with the rockslide will not be implemented and the D1 route will be led through the Korbelka tunnel.

Based on the latest data from geodetic monitoring, the activity of the rockslide movement has a diminishing tendency.

\section{ACKNOWLEDGEMENTS}

This contribution was made possible thanks to the support of projects VEGA $1 / 0530 / 19$ and $1 / 0842 / 18$ by the research agency of the Ministry of Education, Research and Sport of the Slovak Republic.

\section{REFERENCES}

[1] J. Šimeková, P. Liščák, P. Ondrejka, M. Fraštia, M. Kopecký, A. Žilka, M. Kováčik, P. Pauditš, P., D. Balík, 2014: Monitoring of physical activity of an emergency rockslide in the village of Kralovany. Geological works, Reports 122, ed. Dionýz Štúr State Geological Institute, Bratislava, p. 7 - 27. ISSN 0433-4795. 2014.

[2] A. Grenčíková, A. et al. Highway D1 Turany - Hubová. Orientational engineering geological investigation for modified section - variant V1 and subvariant V1a. Final report. Geofos s.r.o. Žilina. 2014.

[3] J. Novotný, I. Novotná I. Report on the geotechnical evaluation of variant 1 of the construction of the D1 motorway in the section Turany - Hubová at the landslide site within the project documentation in the stage of the Comparative Study, Arcadis Praha, 46 p. 2014.

[4] J. Kondela, M. Prekopová, V. Budinský, et al. The importance of seismic methods application for geological reconstruction of rockslide threatened open pit. Journal of Applied Geophysics 159, 2018. DOI:10.1016/j.jappgeo.2018.09.005

[5] P. Tupý P. A. Ilkanič, Z. Jasovský Z. Emergency measures in the locality of Kralovany (Š́tovo quarry). Orientative investigation. Envigeo a.s. Banska Bystrica. 17 pages, 8 appendices. 2014.

[6] M. Fraštia, M. Marčiš, M. Kopecký, et al. Complex geodetic and photogrammetric monitoring of the kral'ovany rock slide. Journal of Sustainable Mining 13:12-16, 2014. DOI:10.7424/jsm140403. 